\title{
Basics for the potential use of saliva to evaluate stress, inflammation, immune system, and redox homeostasis in pigs
}

\author{
J. J. Cerón', M. D. Contreras-Aguilar', D. Escribano1,2, S. Martínez-Miró², M. J. López-Martínez',

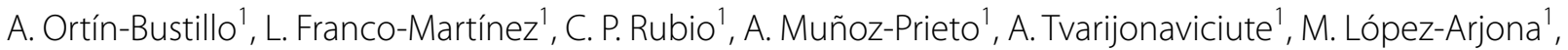 \\ S. Martínez-Subiela ${ }^{1 *}$ and F. Tecles ${ }^{1}$
}

\begin{abstract}
The use of saliva as a biological sample has many advantages, being especially relevant in pigs where the blood collection is highly stressful and painful, both for the animal and the staff in charge of the sampling. Currently one of the main uses of saliva is for diagnosis and detection of infectious diseases, but the saliva can also be used to measure biomarkers that can provide information of stress, inflammation, immune response and redox homeostasis. This review will be focused on the analytes that can be used for such evaluations. Emphasis will be given in providing data of practical use about their physiological basis, how they can be measured, and their interpretation. In addition, some general rules regarding sampling and saliva storage are provided and the concept of sialochemistry will be addressed. There is still a need for more data and knowledge for most of these biomarkers to optimize their use, application, and interpretation. However, this review provides updated data to illustrate that besides the detection of pathogens in saliva, additional interesting applicative information regarding pigs' welfare and health can be obtained from this fluid. Information that can potentially be applied to other animal species as well as to humans.
\end{abstract}

Keywords: Biomarkers, Inflammation, Immune system, Oxidative status, Pigs, Saliva, Stress

\section{Background}

The use of saliva as a biological sample has many advantages, mainly related to its collection. It can be obtained by non-invasive and usually easy procedures, and the sampling does not produce pain. In addition, repeated specimens can be obtained anytime, anywhere, and without the need for specialized staff. Therefore, it is very suitable for monitoring purposes having many potential applications both in the veterinary and human field [1-4].

\footnotetext{
*Correspondence: silviams@um.es

1 Interdisciplinary Laboratory of Clinical Analysis, Interlab-UMU, Regional Campus of International Excellence 'Campus Mare Nostrum', University of Murcia, 30100 Murcia, Spain

Full list of author information is available at the end of the article
}

These advantages are especially relevant in pigs where the blood collection is highly stressful and painful, both for the animal and the staff in charge of the sampling $[5,6]$. Therefore, the use of saliva in this species can be very appropriate on-farm and also in research. On farms, personnel can readily take the samples, leading to the possibility of more frequent analysis and better control of health and welfare (Fig. 1). This can allow faster and more focused interventions and therefore can produce a general improvement in quality and productivity [7]. In research projects on pigs, the saliva could substitute blood in some cases, such as measuring cortisol for stress evaluation $[5,8]$. The no need for blood extraction in the experimental procedures will increase animal welfare, allowing better fulfilment of the Animal Research Care and Use Guidelines requirements. 


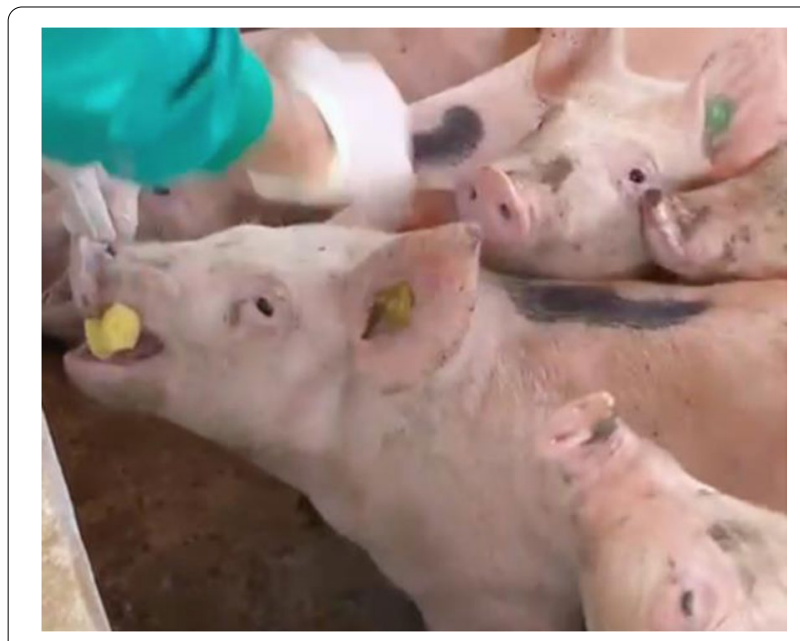

Fig. 1 Saliva sampling in pigs

Looking more deeply into saliva applications, a comprehensive review of its use for the detection of pathogens in pigs has been recently published [9]. According to this publication, more than 23 viral pathogens can be detected in swine saliva, and currently the detection of infectious diseases is possibly the main use of saliva in routine practice in this species. However, the saliva can also be used to assess other aspects related to the pig health and welfare that can be of interest, such as the evaluation of stress, inflammation, immune response and redox homeostasis (Fig. 2). This review will be focused on these other aspects, giving information about the analytes that can be used for such evaluations. Emphasis will be given in providing data about their physiological basis, how they can be measured, and their interpretation in a concise and clear way that could be of practical use.
In addition, a point about some general rules regarding sampling and saliva storage will be included, and the concept of sialochemistry will be addressed.

It is very important to point out that there is still a need for more data and knowledge for most of these biomarkers to optimize their use, application, and interpretation. The generation of this data in the future will help to better define the possibilities of saliva to evaluate stress, inflammation, immune system and redox status in pigs. However, it is expected that this review can help to extend the idea that besides the detection of pathogens, there is other interesting applicative information regarding pigs' welfare and health that can be obtained from this fluid.

\section{Evaluation of stress}

Detailed information about the main causes, consequences, and general biomarkers of stress in pigs can be found in a previous review [6]. In this point, we will focus on the biomarkers of saliva, and we will study: (1) cortisol that evaluates the hypothalamic-pituitary-adrenal axis (HPA), (2) salivary alpha-amylase (sAA) and chromogranin A ( $\mathrm{CgA})$ that are related to the autonomous nervous system (ANS), (3) total esterase (TEA) and some of their components such as salivary lipase (sLip) and butyrylcholinesterase (BChE) which are enzymes that have been related to situations of pain and discomfort. In addition, we will address the (4) oxytocin (OT), which is having a growing interest as a marker of positive emotions.

\section{Cortisol}

\section{Physiology and measurement}

Currently, cortisol is possibly the most widely used biomarker to detect stress in pigs. When a stressful condition occurs, there is an activation of the HPA axis and the

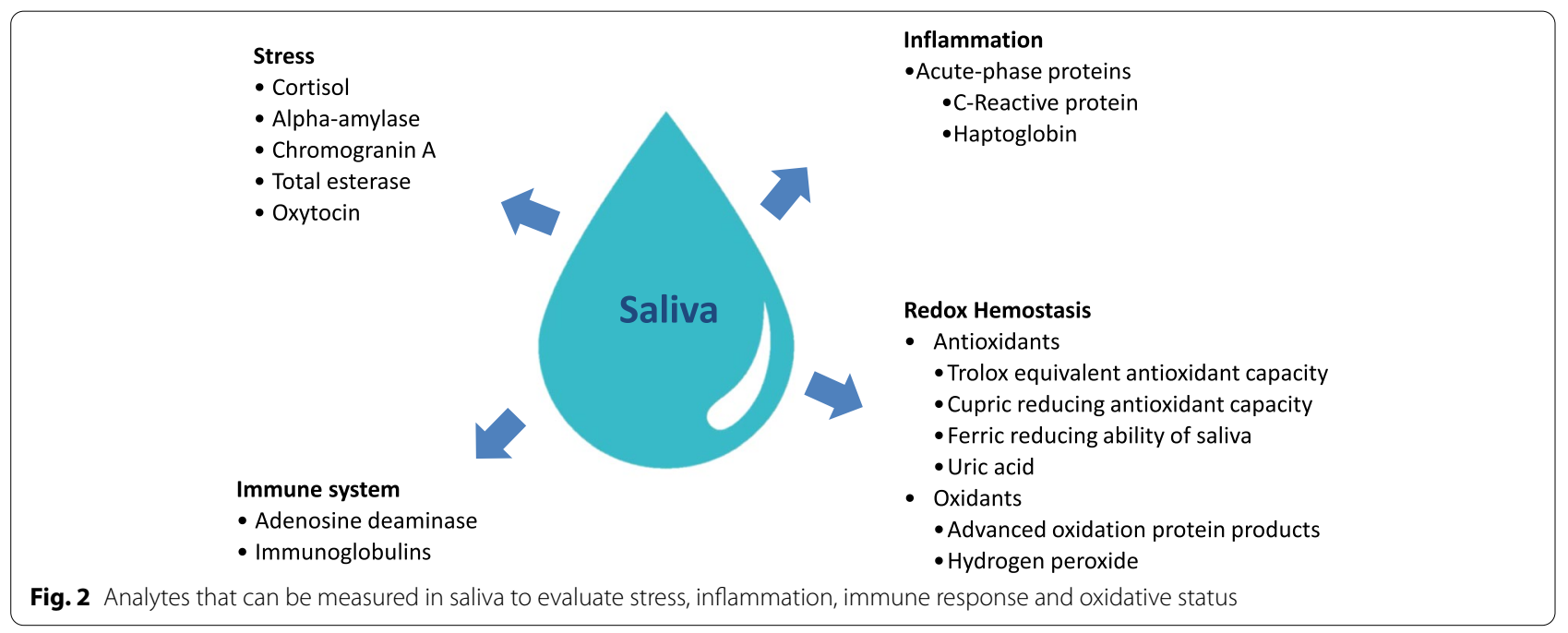


production of cortisol that is released into the blood. In blood, cortisol is present in two fractions: protein-bound cortisol and free cortisol; whereas in the saliva there is only the free cortisol which is the active fraction. The pass of free cortisol from blood to saliva is by passive diffusion of the molecule to the salivary gland [8].

Usually, cortisol in saliva is measured by methods based on antigen-antibody reaction, existing various formats such as radioimmunoassays, enzyme-linked-immunoassays (ELISAs) or automated chemiluminiscence immunoassays that have been validated in the saliva of pigs $[10,11]$. In addition, cortisol in saliva can be measured by mass spectrometry [12].

\section{Interpretation}

There is a high number of published reports published in which cortisol has been measured in the saliva of pigs. Although their detailed description is beyond the objective of this review, some general ideas can be obtained from them that could help in the interpretation of this analyte:

-1. There is variability in the references ranges reported in the literature for cortisol in non-stressed animals and a high intraindividual variation. The mean values for cortisol reported in saliva in adult animals can vary depending on the authors, as can be observed in Table 1 . This could be due to the different types of assays used, and intrinsic factors such as breed or age. It is also important to indicate that cortisol concentrations follow a circadian rhythm in saliva, that can vary with age and sex [13]. The variability between animals can reach a coefficient of variation of cortisol of $62 \%$ in the saliva of nonstressful subjects [5].
Based on the data indicated above, it would be recommended to compare the cortisol concentrations in an individual with the values obtained (a) with the same assay and ideally, (b) in the same animal or group of animals with similar age, breed and sex conditions and without evident signs of stress.

-2. Diverse acute stimuli can produce different increases in salivary cortisol. For example, in a report in which the response of salivary cortisol to different potential acute stressful situations was evaluated, the highest increases in cortisol were obtained for snaring, relocation and vena cava blood sampling. In these situations, cortisol showed the highest values at $15-30 \mathrm{~min}$ after the stimulus, whereas the response to a meal or tail blood sampling did not elicit significant increases in this analyte [5] (Table 2).

-3. The salivary cortisol variation in chronic stress should be evaluated more deeply. There is controversy at this point since although some reports indicated no significant increases in situations of chronic stress [14], other studies suggest that salivary cortisol could be a possible marker of chronic stress in pigs $[15,16]$ as occurs with the cortisol in hair [17]. Therefore, further studies to elucidate the role of salivary cortisol in chronic stress should be performed.

-4. In addition to cortisol, other steroids such as corticosterone or testosterone can be measured in the saliva of pigs. In a report, cortisol in saliva determinations was more sensitive and their results less variable than corticosterone to detect stress [12]. Regarding testosterone, increases in saliva of pigs

Table 1 Some examples of reported values for salivary cortisol in healthy pigs

\begin{tabular}{|c|c|c|c|c|c|c|}
\hline Animals & Breed & Sample size & Method & $\begin{array}{l}\text { Cortisol mean } \\
\text { values ( } \mu \mathrm{g} / \mathrm{L})\end{array}$ & Commentary & Reference \\
\hline $\begin{array}{l}\text { Finishing pigs } \\
\text { (165 days old, } \\
\sim 100 \mathrm{~kg} \text { ) }\end{array}$ & $\begin{array}{l}\text { Duroc } \times \text { [Landrace } \times \\
\text { LargeWhite] }\end{array}$ & 20 & $\begin{array}{l}\text { Immuno-chemilu- } \\
\text { minescence }\end{array}$ & $2.4-7.0$ & & Escribano et al. [10] \\
\hline $\begin{array}{l}\text { Growing pigs } \\
(\sim 105 \text { days old, } \\
\sim 88 \pm 8 \mathrm{~kg})\end{array}$ & $\begin{array}{l}\text { - Duroc } \times \text { [Lan- } \\
\text { drace } \times \text { Large White }] \\
\text { - L62 }(\text { a crossed } \\
\text { of several geno- } \\
\text { types }) \times[\text { Lan- } \\
\text { drace } \times \text { Large White }] \\
\text { - Pietrain } \times[\text { Lan- } \\
\text { drace } \times \text { Large White }]\end{array}$ & $\begin{array}{l}12 \text { samples from } \\
\text { ropes (10-12 ani- } \\
\text { mals per rope) }\end{array}$ & $\begin{array}{l}\text { Liquid chromatog- } \\
\text { raphy-tandem mass } \\
\text { spectrometry }\end{array}$ & $\begin{array}{l}\cdot 1.20 \pm 0.20 \\
\cdot 0.51 \pm 0.05 \\
\cdot 0.74 \pm 0.30\end{array}$ & $\begin{array}{l}\text { No individual sam- } \\
\text { ples were measured, } \\
\text { but } 12 \text { rope samples } \\
\text { from } 4 \text { different } \\
\text { farms ( } 3 \text { ropes per } \\
\text { farm) }\end{array}$ & $\begin{array}{l}\text { Rey-Salgueiro et al. } \\
{[12]}\end{array}$ \\
\hline $\begin{array}{l}\text { Nulliparous non- } \\
\text { pregnant gilts } \\
\text { (8-9 months old, } \\
\sim 150-170 \mathrm{~kg} \text { ) }\end{array}$ & $\begin{array}{l}\text { Large White } \times \\
\text { Landrace }\end{array}$ & 91 & Radio immunoassay & $0.8-2.2$ & $\begin{array}{l}\text { Samples correspond } \\
\text { to } 8 \text { gilts repeatedly } \\
\text { sampled at different } \\
\text { days }\end{array}$ & Merlot et al. [5] \\
\hline
\end{tabular}


Table 2 Some examples of cortisol (saliva and plasma) responses after different stressful stimuli [5]

\begin{tabular}{|c|c|c|c|c|c|}
\hline Animals & Stressful condition & Sample size & Sampling times & $\begin{array}{l}\text { Cortisol values }(\mu \mathrm{g} / \mathrm{L}) \text { : } \\
\text { (Before stress vs peak } \\
\text { after stress) }\end{array}$ & Commentary \\
\hline \multirow[t]{3}{*}{$\begin{array}{l}\text { Nulliparous non-preg- } \\
\text { nant gilts }(8-9 \text { months of } \\
\text { age, } \sim 150-170 \mathrm{~kg})\end{array}$} & $\begin{array}{l}\text { Vena cava blood sam- } \\
\text { pling }\end{array}$ & 8 & $\begin{array}{l}\text { Before and } 15,30,60,90 \\
\text { and } 120 \text { min after the } \\
\text { stressful condition }\end{array}$ & $\begin{array}{l}\text { - Saliva (1.7 vs 3.2) } \\
\text { - Plasma (10.5 vs 35.8) }\end{array}$ & $\begin{array}{l}\text { - In saliva peaked at } 15 \text { min } \\
\text { - In plasma peaked at } \\
15 \text { min, still increased at } \\
30 \text { min } \\
\text { (no significant changes at } \\
\text { other times) }\end{array}$ \\
\hline & Snaring & 8 & & $\begin{array}{l}\text { - Saliva (0.8 vs 5.1) } \\
\text { - Plasma (11.8 vs } 47.4)\end{array}$ & $\begin{array}{l}\text { - In saliva peaked at } 15 \mathrm{~min} \text {, } \\
\text { still increased at } 30 \mathrm{~min} \\
\text { - In plasma peaked at } \\
15 \mathrm{~min} \text {, still increased at } \\
60 \text { min } \\
\text { (no significant changes at } \\
\text { other times) }\end{array}$ \\
\hline & Relocation & 8 & & $\begin{array}{l}\text { - Saliva (1.5 vs 3.3) } \\
\text { - Plasma (8.9 vs } 35.0)\end{array}$ & $\begin{array}{l}\text { - In saliva peaked at } 15 \text { min, } \\
\text { still increased at } 30 \text { and } \\
60 \text { min } \\
\cdot \text { In plasma peaked at } \\
15 \text { min, and increased until } \\
120 \text { min }\end{array}$ \\
\hline
\end{tabular}

in different stressful situations have been described [18], and interestingly increases in testosterone with cortisol values in reference range have been associated with predisposition to aggressive behavior in humans [19].

\section{Salivary alpha-amylase (sAA) and chromogranin-a (CgA)}

\section{Physiology and measurement}

Both biomarkers are directly produced by the stimulation of the salivary glands by the ANS.sAA can be directly quantified by immunoassays, or it can be evaluated by its enzymatic activity by spectrophotometric assays, being the last one more sensitive to detect stressful conditions in pigs [20] and humans [21]. CgA can be measured by immunoassays in the saliva of pigs [22]. The assays used for the measurements of SAA and/or CgA are easier to perform and cheaper than the analysis of adrenalin and nor-adrenalin, which are the classical analytes used to evaluate the sympathetic activity.

\section{Interpretation}

Some general ideas can help in the understanding of these analytes:

-1. CgA and sAA can increase in situations of acute stress (Table 3). After acute stress induced by a snaring, sAA and CgA showed variability in their response and even did not increase in some pigs $[20,22,23]$. This situation also happens with cortisol [22], and although it is not known the cause, it reflects a variability in the individual response to this model of acute stress. In this line, sAA can increase from values lower than $100 \mathrm{IU} / \mathrm{L}$ to higher than $1000 \mathrm{IU} / \mathrm{L}$, with some individuals reaching up to $4000 \mathrm{IU} / \mathrm{L}$, at the moment of the stress induction by snaring in some pigs, whereas it does not change in other pigs [20]. CgA was reported to increase in a snaring around 1.2-fold just after $10 \mathrm{~min}$ of continuous restraining [24] and from values lower than $2 \mathrm{mg} / \mathrm{L}$ to up to $3 \mathrm{mg} / \mathrm{L}$ after $15 \mathrm{~min}$ of ceasing the snaring [22]. In a model of restraining by enclosure in a steel cage for $60 \mathrm{~min}$, the increase in CgA was higher than 4-fold and persisted increased 2-3-fold at $30 \mathrm{~min}$ after ceasing the stimulus [24]. This could indicate a possible relation of this marker with stress of longer duration as will be discussed later.

In some cases, there can be divergences between sAA and CgA. For example at weaning, which is a known stressful condition, there were increases in salivary $\mathrm{CgA}$, which were correlated with skin lesions, but sAA did not show changes [25]. Although no data exist regarding sAA, CgA in saliva of pigs seems to be not affected by circadian rhythms [26].

-2. The behavior of CgA and $s A A$ in saliva in chronic stress should be evaluated more deeply. Although both biomarkers are related to the ANS, and therefore to the reaction occurring after acute stress, changes in CgA and sAA have been described in situations of stress of longer duration, for example: 


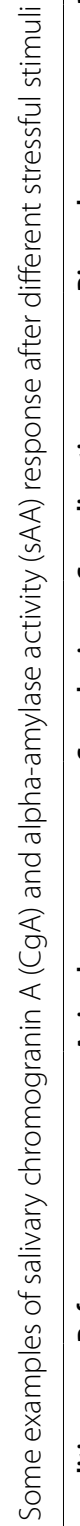

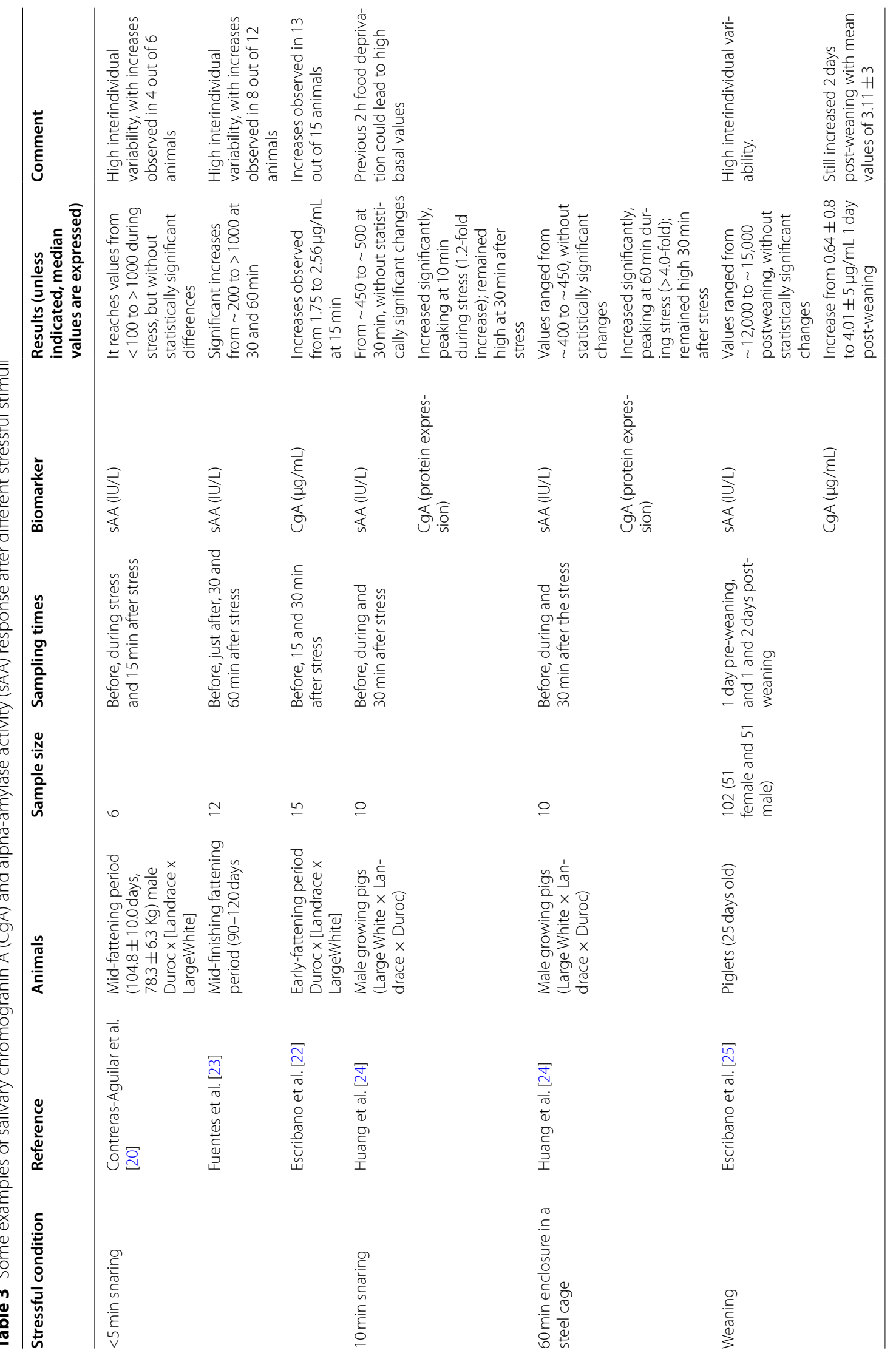


- sAA showed increases in pigs suffering pain due to lameness and rectal prolapse [27]. The animals with these disorders showed even higher increases in sAA (7.49-fold and 18.20-fold in most severe cases of lame and prolapsed animals, respectively, compared to healthy animals) than in other biomarkers such as cortisol (1.72-fold and 2.30 -fold in lame and prolapsed animals, respectively). Maybe the longer duration of the pain could have influenced the higher values of sAA [27].

- Although the mechanism is not well known, CgA decreased in saliva after different types of environmental enrichment and herbal supplementation during 2 months in growing pigs, from values of $1 \mathrm{mg} / \mathrm{L}$ to values lower than $0.3 \mathrm{mg} / \mathrm{L}$. This could indicate a reduction in the stress of these pigs during this period. In addition, CgA in saliva showed a low to moderate, but significant, correlation with cortisol concentration in hair [28].

-3. CgA is an early biomarker of postpartum dysgalactia syndrome (PDS). CgA was significantly increased in sows with PDS before farrowing, showing a higher sensitivity than other markers such as cortisol. Although the reason for this increase is unknown, the high values of CgA could indicate a situation of stress with activation of the adrenergic system that could be involved in the pathogenesis of this disease. In addition, there could be a role of CgA in the gastrointestinal disorders associated with PDS, since in the human gastrointestinal tract, $\mathrm{CgA}$ is released from enterochromaffin cells and neurons of the submucosal and myenteric ganglia, and may modulate colonic motility in response to inflammation [29].

\section{Total esterase activity (TEA) and its components Physiology and measurement}

TEA is abundant in the saliva of pigs [30]. Several enzymes contribute to this esterase activity:

- Cholinesterase (ChE) and cholesterol esterase represent around $20 \%$ of salivary TEA activity in healthy non-stressed pigs [30]. Whereas acetylcholinesterase is the predominant form in human saliva [31], butyrylcholinesterase (BChE) is the predominant isoenzyme in porcine saliva [32]. The origin and function of $\mathrm{ChE}$ in saliva remain unknown, but the lack of correlation between serum and salivary ChE [33] supports the idea that the enzyme could be secreted by the salivary gland. In addition, ANS activity could be implied in ChE production [34].

- Salivary lipase (sLip) could be around 30\% in healthy non-stressed pigs. Although its main function is related to triglyceride digestion, lipase secretion by salivary glands could also be related to the activation of the sympathetic nervous system [35].

- Carbonic anhydrase isoenzyme 6 (CA-VI) could represent up to $50 \%$ of the TEA activity in porcine saliva [30]. In humans, this enzyme (also called gustin) is related to taste function and taste bud growth [36]. Despite this, its secretion is also related to the sympathetic nervous system [37].

TEA, BChE and sLip can be measured spectrophotometrically, and there are assays validated for pigs [30, 32].

\section{Interpretation}

1. Salivary TEA can increase in situations of acute stress. Increased salivary TEA activity in pigs, with an increase of 1.49-fold just after the stimulus, has been described after a restraining by nasal snare. In addition, an increase (1.8-fold) in salivary TEA was reported at $4 \mathrm{~h}$ after transport and lairage at slaughterhouse compared with values before transport. This increase was lower than those observed with other biomarkers such as cortisol [38].

2. The behavior of TEA in saliva in chronic stress should be evaluated more deeply. Salivary TEA could also be increased in pigs suffering pain due to lameness and rectal prolapse [27]. Therefore, further studies would be of interest to evaluate the behavior of TEA in situations of pain or stress of long duration.

3. The change of the different components of salivary TEA can provide additional information. Measuring some components of TEA such as BChE and sLip could provide additional information since the changes observed in those enzymes can be different depending on the stressful stimulus. For example, in case of acute stress such as a nasal restraining or transport and lairage at slaughterhouse during $4 \mathrm{~h}$, $\mathrm{BChE}$ could be increased more than 5-fold compared with the pre-stress values [32], being more sensitive than TEA (which increased less than 2-fold) [30] (Table 4).

\section{Oxytocin (OT) \\ Physiology and measurement}

OT is a hormone that, in addition to its physiological role in labour and lactation, is considered a biomarker of positive emotions and social well-being in domestic animals. 
Table 4 Some examples of salivary total esterase activity (TEA), butyrylcholinesterase (BChE) and lipase response after different stressful stimuli

\begin{tabular}{|c|c|c|c|c|c|c|c|}
\hline $\begin{array}{l}\text { Stressful } \\
\text { condition }\end{array}$ & Reference & Animals & Sample size & Sampling times & & $\begin{array}{l}\text { Results } \\
\text { (UI/L, unless } \\
\text { indicated, } \\
\text { median values } \\
\text { are expressed) }\end{array}$ & Comment \\
\hline $\begin{array}{l}\text { Transport and } \\
\text { lairage to slaugh- } \\
\text { terhouse }\end{array}$ & $\begin{array}{l}\text { López-Arjona } \\
\text { et al. [38] }\end{array}$ & $\begin{array}{l}\text { Female at end- } \\
\text { fattening period } \\
\text { ( } 5-6 \text { months) } \\
\text { LargeWhite x } \\
\text { Pietrain }\end{array}$ & 45 & $\begin{array}{l}\text { Before, imme- } \\
\text { diately after } \\
\text { and at } 4 \mathrm{~h} \text { from } \\
\text { transport }\end{array}$ & TEA (IU/L) & $\begin{array}{l}\text { - Before trans- } \\
\text { port:151.7 } \\
\text { - Just after: } 190.6 \\
\text { - After 4h: } 277.8\end{array}$ & \\
\hline $\begin{array}{l}\text { Disease (lame- } \\
\text { ness and rectal } \\
\text { prolapse) }\end{array}$ & $\begin{array}{l}\text { Contreras-Aguilar } \\
\text { et al. [27] }\end{array}$ & $\begin{array}{l}\text { Male mid fat- } \\
\text { tening period } \\
\text { (60-90 days) } \\
\text { (Large White) }\end{array}$ & 60 & $\begin{array}{l}\text { Just only one } \\
\text { sampling }\end{array}$ & TEA (IU/L) & $\begin{array}{l}\text { - Healthy: } 128.8 \\
\text { - Lame: } 293.2 \\
\text { - Prolapsed: } 780\end{array}$ & \\
\hline \multirow[t]{3}{*}{2 min snaring } & \multirow[t]{2}{*}{ Tecles et al. [30] } & \multirow{3}{*}{$\begin{array}{l}\text { Male growing } \\
\text { pigs (Large White } \\
\times \text { Landrace } \times \\
\text { Duroc) }\end{array}$} & \multirow[t]{3}{*}{20} & \multirow{3}{*}{$\begin{array}{l}\text { Before, just after } \\
\text { and at } 15 \mathrm{~min} \\
\text { after the stress }\end{array}$} & TEA & $\begin{array}{l}\text { 1.49-fold increase } \\
\text { just after stress }\end{array}$ & $\begin{array}{l}\text { Returned to basal } \\
\text { values at } 15 \mathrm{~min}\end{array}$ \\
\hline & & & & & Lipase & $\begin{array}{l}1.60 \text {-fold increase } \\
\text { at } 15 \text { min after } \\
\text { stress }\end{array}$ & $\begin{array}{l}\text { No increase just } \\
\text { after stress }\end{array}$ \\
\hline & Tecles et al. [32] & & & & $\begin{array}{l}\text { BChE (nmol/min/ } \\
\mathrm{mL})\end{array}$ & $\begin{array}{l}5.25 \text {-fold increase } \\
\text { just after stress }\end{array}$ & $\begin{array}{l}\text { Still increased at } \\
15 \mathrm{~min}\end{array}$ \\
\hline
\end{tabular}

The increase of OT with positive welfare situations is in contrast with the rest of the biomarkers of stress used until now, which increase when there is a stressful situation or negative welfare [39]. The source of OT in the saliva is unknown, but a recent report in humans indicates that salivary OT can reflect endogenous concentration and production. In this paper, repeated intranasal administration of OT induced long-lasting changes in endogenous salivary OT levels, presumably through a positive spiral of OT release [40].

In the saliva of pigs, as in other species, OT can be in two main forms: linked to proteins or free. In addition, different OT metabolites can exist [41, 42]. Usually, immunoassays are used to measure OT in saliva, and recently two assays, which do not need extraction or lyophilization, were specifically validated for pigs' saliva . One seemed to have more affinity for detecting the OT linked to proteins, whereas the second one ould detect other forms [39]. In addition to these immunoassays, other assays that usually need reduction and alkylation [42] or extraction [43] have been applied in pigs. Although there are no studies in pigs, high-performance liquid chromatography-mass spectrometry (HPLC-MS) can also be used for detection of OT in saliva, giving in general lower values of OT concentrations than immunoassays [44].

\section{Interpretation}

As other biomarkers, the knowledge about OT measurements in the saliva of pigs is in its beginning, but there is some information that can be of interest and application (Table 5):

1. Different assays can measure diverse OT forms or metabolites and give different values. For example, in the report where two different assays were validated in the saliva of pigs, one gave values in $\mu \mathrm{g} / \mathrm{L}$, whereas the other gave values in ng/L of OT [39]. In addition, it should be pointed out the intraindividual variability of OT values, since in one report in a group of 45 adult pigs the 25 th and 75 th percentiles values could reach to 2-fold the mean values [38]. More details about the ability of different assays to give diverse values can be found in a recent review [41].

2. Some physiological conditions such as farrowing and lactation can produce changes in OT in saliva. OT concentrations were significantly higher at the beginning of lactation, and also these changes were differently detected depending on the assay used. In this case, a commercially available assay was less sensitive to detect these changes [42].

3. OT in saliva can decrease in situations of acute stress. In a report, decreases in salivary OT concentrations were found in pigs at $4 \mathrm{~h}$ of lairage at a slaughterhouse. This could indicate a reduction of positive feelings in this situation, possibly due to various stressful stimuli such as the unloading process, mixing with unfamiliar pigs and stranger sounds. Depending on the assay used, these decreases were of different magnitude (42.2\% versus $27.5 \%$ ), so also the 


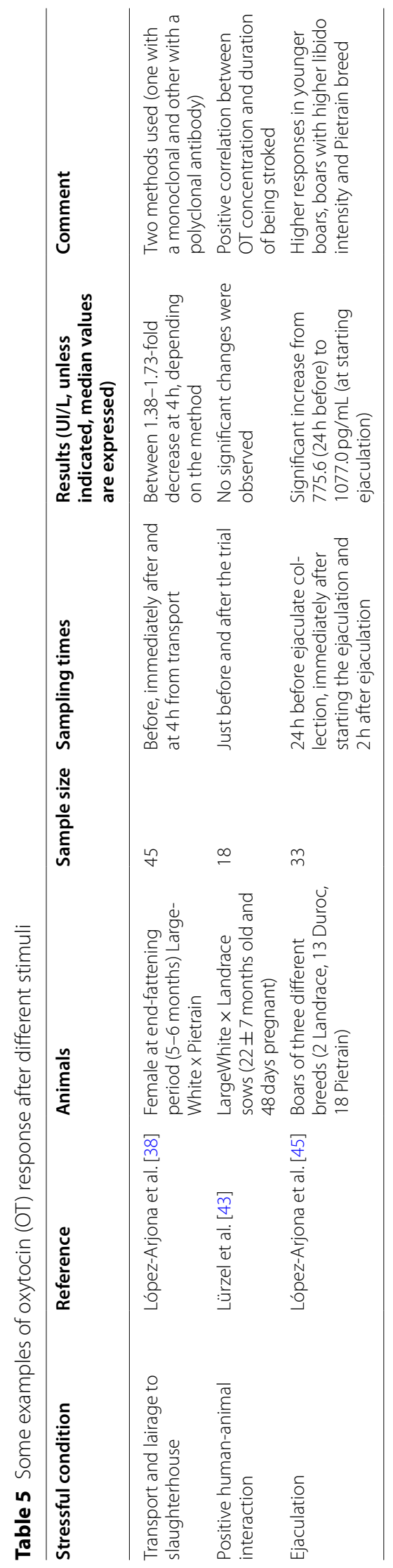




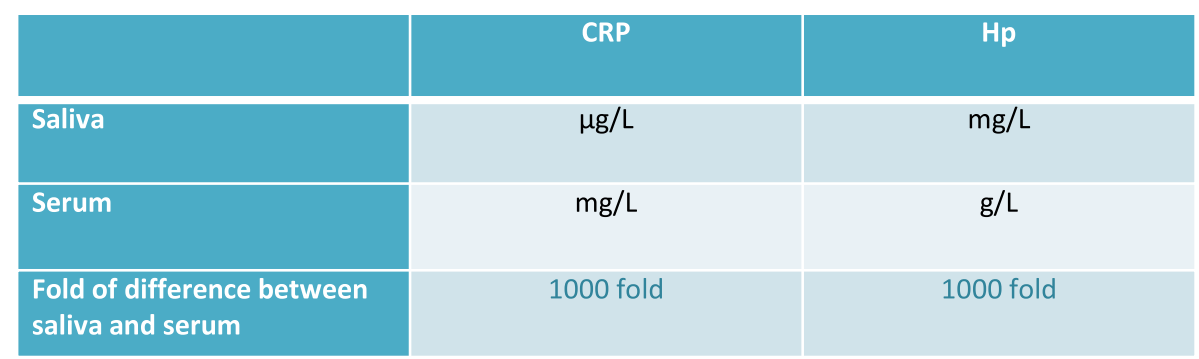

Fig. 3 Units of measurement of CRP and $\mathrm{Hp}$ in saliva and serum and fold change [7]

type of assay can influence the detection of changes after stressful situations [38].

4. OT can increase by positive interactions. In a study in which positive human-animal interactions were evaluated in pigs, the concentration of OT in saliva was associated positively with being stroked [43]. In addition, ejaculation increases salivary OT concentrations in breeding boars [45]. Therefore, this data suggest that this hormone can be a marker of positive emotions.

\section{Evaluation of inflammation \\ Acute phase proteins (APPs) \\ Physiology and measurement}

APPs are proteins that change in concentrations in response to inflammation, being considered the most sensitive and early biomarkers for this process. Recently, based on the knowledge about physiology and clinical application of these proteins, an updated seven-point plan for the APPs use and interpretation in veterinary medicine was reported, that can also be applied to saliva in pigs [7].

The most important particularity regarding APPs measurements in saliva is the fact that concentrations of most important APPs such as C-reactive protein (CRP) or Haptoglobin (Hp) are at approximately 1000-fold lower concentrations in saliva than in serum. For example, in the case of CRP the concentration in serum is in $\mathrm{mg} / \mathrm{L}$, whereas in saliva is $\mu \mathrm{g} / \mathrm{L}$. A similar fact happens for $\mathrm{Hp}$, being in serum in $\mathrm{g} / \mathrm{L}$ but in the saliva in $\mathrm{mg} / \mathrm{L}$ [7] (Fig. 3). This would be the reason why some attempts to measure APPs in the saliva with conventional assays can have no success. Therefore, the use of more sensitive assays to detect APPs in the saliva are recommended. For example, time-resolved fluorometric or alphalisas assays have been successfully used to measure APPs in the saliva of pigs and other species as humans [46, 47]. Alphalisa assays have as their main advantages the use of a lower sample volume and the no need for washing steps [47].
The mechanisms which are responsible for the presence of APPs in saliva are still to be elucidated. However, in pigs as in other species such as dogs or humans, some APPs like CRP were significantly correlated in saliva and serum; and recently a transport process for CRP from blood to saliva in humans has been described [48].

\section{Interpretation}

As a general idea, the rules for interpretation of APPs in saliva in pigs will be similar to those reported for other species [7]. However, some particularities can be indicated for saliva and can help in the interpretation of the results obtained:

-1. Although baseline values are lower than in serum, the distinction between major and moderate APPs can also be made in saliva. Hp values in the saliva of healthy adult pigs are usually lower than $1 \mathrm{mg} / \mathrm{L}$ and can reach to $3-4 \mathrm{mg} / \mathrm{L}$ in pigs with inflammation, whereas CRP in healthy animals usually has lower values than $10 \mu \mathrm{g} / \mathrm{L}$ and can reach values up to $100 \mu \mathrm{g} / \mathrm{L}$ in inflammation [49] (Table 6). This could indicate that, as reported in serum [52], $\mathrm{Hp}$ is a moderate acute phase protein, whereas CRP is a major APPs in saliva of pigs. This could also explain that in the case of some more chronic inflammatory states, salivary $\mathrm{Hp}$ might be a more sensitive marker than CRP [49], possibly due to the moderate nature of $\mathrm{Hp}$ that maintain its increases during longer time.

-2. APPs are highly sensitive to detect inflammation, but they have a low specificity to detect the cause of inflammation. The APPs can detect inflammation with high sensitivity and very early, in many cases before the appearance of clinical signs, being an excellent marker of the presence of subclinical diseases. However, they usually do not provide information about the cause of inflammation; therefore, it should be combined with other tests or clinical data. For example, if an infectious disease is sus- 


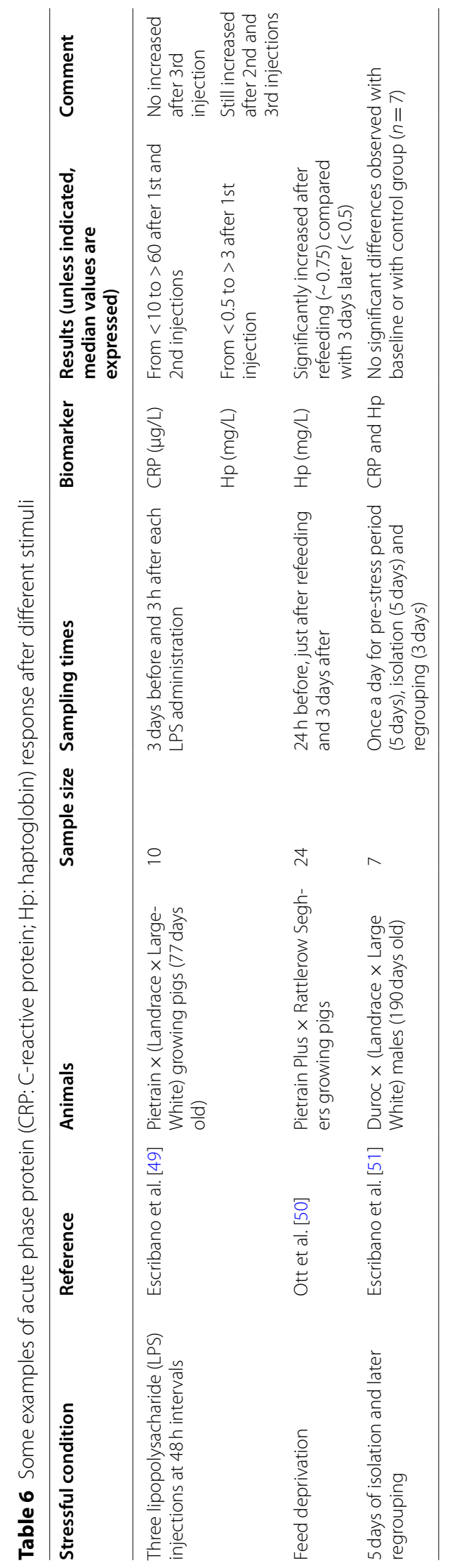


pected, the detection of the pathogen, which could also be made in saliva [9], would be recommended.

In line with this low specificity, increases in APPs in saliva have been found not only in inflammation but also in stress situations. However, the relation between APPs and stress is controversial. For example, $\mathrm{Hp}$ in saliva increased in stress induced by feed deprivation [50] and a link between APPs and stress has been hypothesized [53]. However, in other stress situations no changes in APPs have been found. For example, pigs exposed to a psychosocial stressor, that increased their cortisol levels, did not increase the Hp and CRP concentrations in saliva [51].

\section{Evaluation of immune system Adenosine deaminase (ADA) Physiology and measurement}

ADA is a ubiquitously expressed enzyme that appears in saliva. It has two isoenzymes: ADA1 and ADA2, which have a role in the differentiation of $T$ lymphocytes. Total ADA (tADA) activity represents the sum of the activity of the two isoenzymes, and in humans its measurement in serum has been used as a biomarker of cell-mediated immunity and chronic inflammation [54, 55]. There is still a lack of knowledge about the origin and sources of ADA in saliva, being the clarification of this aspect of high interest, since for example tADA in pigs is over 100fold higher than in serum $[56,57]$.

The activities of tADA and its isoenzymes can be measured in saliva by a three-step procedure [57]: (1) the sample is measured for evaluation of tADA by a spectrophotometric assay; (2) the sample is measured again with the same assay adding Erythro-9-2-hydroxy-3-nonyl adenine (EHNA), which is an inhibitor of ADA1, at the appropriate concentration for ADA2 estimation; and (3) the isoenzyme ADA1 is calculated by the difference between measurements of step 1 and 2 .

\section{Interpretation}

Although the knowledge about ADA is still in its infancy, currently some data can be given that could be used for its interpretation (Table 7):

-1. ADA is present in high amounts in the saliva of pig. Compared with other species such as dogs, horses, or cows, pigs showed the highest tADA values in saliva [57].

-2. ADA increases in saliva in inflammatory diseases. In saliva, significant increases have been reported in tADA and ADA1 in pigs with lameness compared with healthy pigs. This study showed a high correlation between tADA and its isoenzymes with serum CRP, indicating that salivary ADA activities are related to inflammation [57]. It is important to point out that, in this study, saliva was more sensitive than serum to detect these changes, being this situation an example in which saliva would be preferred to serum in the measurement of an analyte. Although this should be further explored, ADA could also have potential in pigs as a tool for pain assessment in inflammatory situations such as lameness and rectal prolapse [27].

\section{Immunoglobulins (Igs) Physiology and measurement}

In saliva there are IgG, IgM and IgA. Salivary IgG and IgM are mainly derived from blood, whereas IgA is mainly produced by the salivary glands in plasma cells. IgA concentration seems to be more influenced by stress, whereas IgG and IgM in saliva would be more related to its concentration in serum. Also, it is interesting to indicate that IgM is produced earlier than IgG in disease and both are markers of the humoral acquired immunity, being IgM also related to the innate immune system [5961]. The three different types of Igs can be measured in the saliva of pigs by immunoassays with adequate analytical performance [58] (Table 7).

\section{Interpretation}

-1. The Igs types are at different concentrations in saliva. IgA is in a higher amount in saliva in healthy animals than IgG and IgM; having healthy pigs concentrations of IgA in the range of $100 \mathrm{mg} / \mathrm{L}$, whereas IgG are in $10 \mathrm{mg} / \mathrm{L}$ and $\operatorname{IgM}$ in $20 \mathrm{mg} / \mathrm{L}$ [58].

-2. IgG shows major increases in situations of infectious diseases. Specific IgGs are more used for detection of antibody production against an infectious agent [9]. However, the measurement of their total values can also have clinical value. For example, IgG seems more sensitive than other Igs to differentiate between healthy and diseased pigs with porcine reproductive and respiratory syndrome (PRRS) and post-weaning multisystemic wasting syndrome (PMWS), with a difference of more than 10-fold between groups [58]. Therefore, an increase in IgG in saliva could raise the suspicion of an infectious disease.

-3. IgA can increase in cases of inflammation but also after stressful conditions. Regarding the relation with inflammation, an increase in IgA in saliva was reported associated with endotoxemia with increases from $50 \mathrm{mg} / \mathrm{L}$ in basal levels to a peak of mean values of $400 \mathrm{mg} / \mathrm{L}$ that can even reach $500 \mathrm{mg} / \mathrm{L}$. In addition, it has been postulated that 


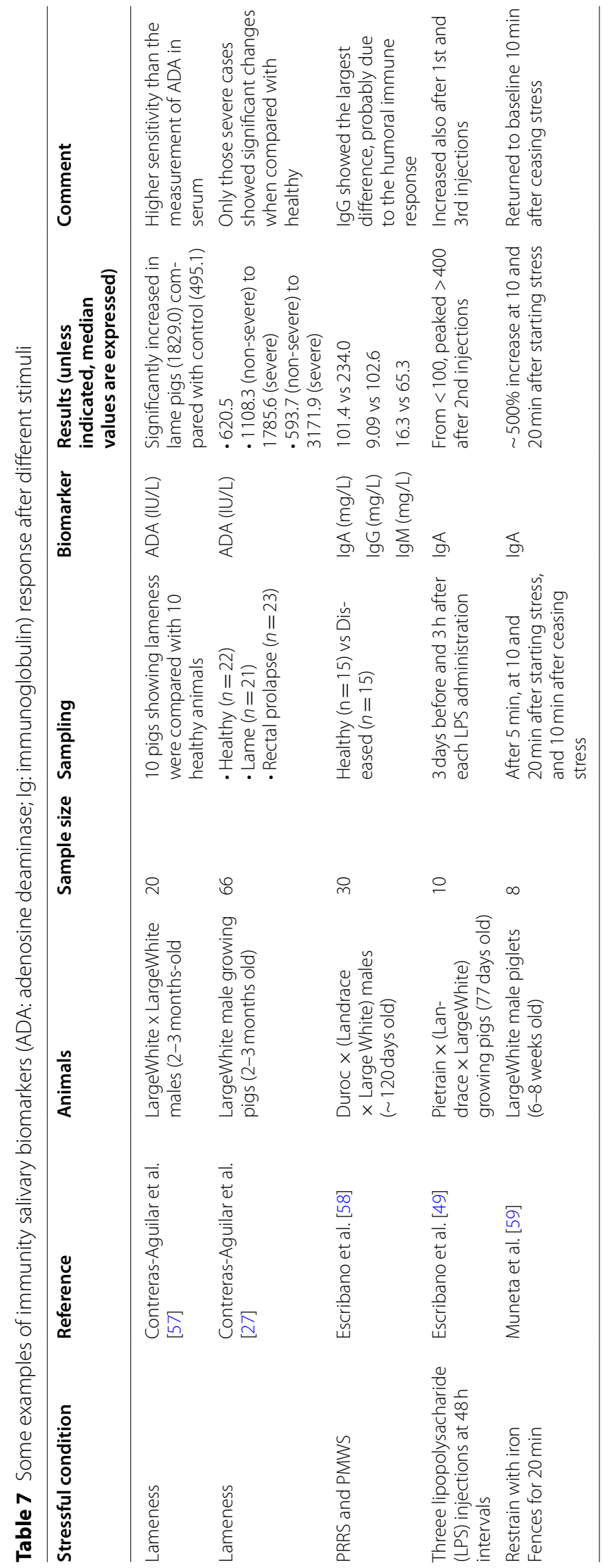


IgA could also be a marker of more chronic inflammatory states [49]. On the other hand, saliva IgAs can increase after different stressful conditions in pigs such as after a restrain stress; from basal levels around $100 \mathrm{mg} / \mathrm{L}$ to a peak of mean values around $500 \mathrm{mg} / \mathrm{L}$ that can even reach $800 \mathrm{mg} / \mathrm{L}$. These increases were higher than those of cortisol and returned to pre-stress levels sooner after removing of the stress [59]. In this line, it has been proposed in humans that salivary secretion of IgA might be linked to the activation of the ANS system [62].

\section{Evaluation of the redox homeostasis Physiology and measurement}

To our knowledge, currently in saliva of pigs it can be measured the total antioxidant capacity (TAC) by three assays: Trolox equivalent antioxidant capacity (TEAC), cupric reducing antioxidant capacity (CUPRAC), and ferric reducing ability of saliva (FRAS, which has the same basis that ferric reducing ability of plasma or FRAP). Moreover, other antioxidants such as uric acid and catalase can be measured. In addition, oxidant biomarkers such as advanced oxidation protein products (AOPP) and hydrogen peroxide $\left(\mathrm{H}_{2} \mathrm{O}_{2}\right)$ can be quantified in porcine saliva $[63,64]$. The origin of these analytes in saliva is unclear, and only CUPRAC showed a significant positive correlation between saliva and plasma values, being this correlation low [63].

All these biomarkers can be measured by spectrophotometric assays and adapted to automated analyzers [63].

\section{Interpretation}

At this time, with the current knowledge we could provide the following ideas about the interpretation of the markers of redox homeostasis:

-1. The values of biomarkers of redox homeostasis in saliva change in some physiological conditions such as farrowing and lactation. Although reference ranges should be established with larger populations and the values could change depending on the assays used and therefore these values should be interpreted with caution; in our experience, the mean values that we usually obtain in the saliva of healthy adult animals are between $0.1-0.5 \mathrm{mmol} / \mathrm{L}$ for TEAC, CUPRAC and FRAS, 30-200 $\mu \mathrm{mol} / \mathrm{L}$ for AOPP and 5-25 $\mu \mathrm{mol} / \mathrm{L}$ for $\mathrm{H}_{2} \mathrm{O}_{2}[27,63,64]$.

There is an increase in antioxidant and oxidant concentrations in the saliva of sows at the first day of lactation, of around 1.2-2 fold, which decreased during the 20 days of lactation, in line with the previously described increases of various biomarkers of oxidative status in serum of sows during early lactation [63].

-2. Changes in biomarkers of redox homeostasis occur in different situations in which there are disturbances in the pig. For example, piglets supplemented with high doses of garlic exhibited decreased antioxidants biomarkers, such as CUPRAC, and increases in oxidant biomarkers such as $\mathrm{H}_{2} \mathrm{O}_{2}$, that could reflect the oxidative effects described in farm animals after the consuming garlic at high doses [64].

In addition, pigs with prolapses and pain showed higher levels of FRAS, AOPP and $\mathrm{H}_{2} \mathrm{O}_{2}$ in saliva compared with the healthy animals, being salivary FRAS and AOPP correlated with the pain of the animals [27].

-3. Interpreting the paradox. On some occasions, a paradox can occur in which increases in antioxidant and oxidants are detected at the same time. This could reflect a situation in which an increase in antioxidants is produced to compensate the overproduction of oxidant compounds that is occurring. This means that, in some cases of oxidative disturbance, the balance would be tried to be reestablished.

-4. It would be recommended in the future to evaluate the salivary biomarkers of redox homeostasis change in selected diseases and establish possible profiles for their evaluation. If possible, these evaluations should include panels with at least two antioxidant and two oxidant biomarkers. These studies will open new possibilities of using saliva as a noninvasive sample to evaluate oxidative stress in pigs.

\section{General recommendations for saliva sampling and management}

We could make the following general recommendations for saliva sampling and management in pigs (Fig. 4):

-1. The use of sponges. This allows to obtain stimulated saliva with less mucin content and therefore reduced viscosity leading to easier processing and management of the samples.

-2. If samples are not processing in a short time, refrigeration or a least keeping them in a cool place is recommended, until their arrival to the laboratory.

-3. Samples should be centrifuged to remove cell and food debris. The protocol of centrifugation that we use at our laboratory is $3.000 \times \mathrm{g}$ for $10 \mathrm{~min}$ at $4{ }^{\circ} \mathrm{C}$.

-4. Ideally, samples should be stored at $-20^{\circ} \mathrm{C}$ or $-80^{\circ} \mathrm{C}$ if they will not be analyzed immediately. 


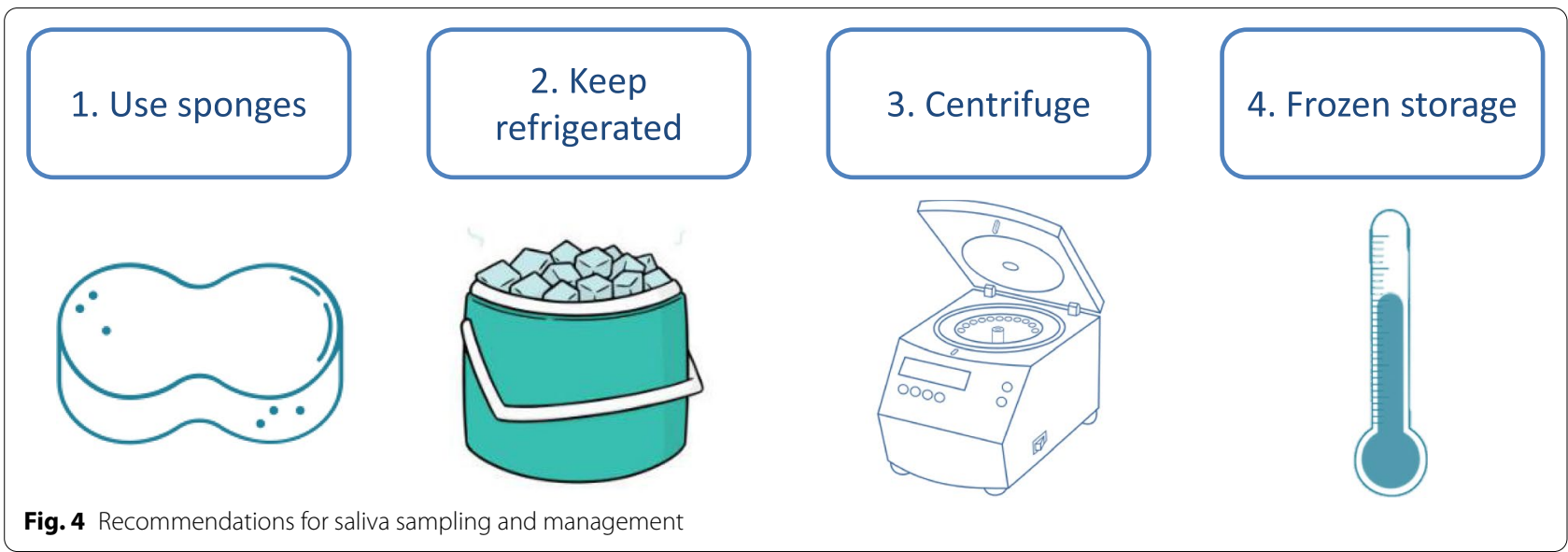

The optimal temperature for storage depends of the analyte. For example, $\mathrm{CgA}$ and ADA are stable in saliva 1 year stored at $-20^{\circ} \mathrm{C}$; whereas $-80^{\circ} \mathrm{C}$ is recommended for prolonged storage of sAA or $\mathrm{BChE}$ and the enzymes and biomarkers of oxidative stress in general $[26,65]$. Overall, at $-80^{\circ} \mathrm{C}$, the analytes are more stable than at $-20^{\circ} \mathrm{C}$. Information about how analytes in saliva can be stable at different storage conditions has been reported in pigs [65] and humans [66].

\section{Future perspectives: the concept of sialochemistry}

In addition to the analytes described here, it is gaining attention the concept of sialochemistry, which is the application in saliva of the same or similar analytical profiles that are used in routine for the clinical biochemistry of serum.

For example, a profile of a total of 11 analytes including aspartate aminotransferase (AST), alkaline phosphatase (ALP), $\gamma$-glutamine transferase (GGT), lactate dehydrogenase $(\mathrm{LDH})$, creatine kinase $(\mathrm{CK})$, urea, creatinine, triglycerides, lactate, calcium and phosphorus was validated from the analytical point of view in the saliva of pigs with satisfactory results [67]. One advantage of this sialochemistry profile is the fact that most of the assays included are measured by spectrophotometric methods and can be easily set up in saliva with the commercially available reagents that are usually employed in clinical chemistry laboratories, being easily adapted to automated analyzers, manual or automated spectrophotometers or plate readers.

In addition, changes in this profile were studied in gestation, farrowing and lactation. Increases in muscle and hepatic enzymes (CK, AST, ALP, GGT and $\mathrm{LDH})$ were detected at farrowing, and triglycerides increased at the end of gestation and remained at high concentrations until the end of lactation [46]. In particular, LDH is also increased in situations of reduced welfare in pigs [68]. In other species such as dogs, increases in urea and creatinine in saliva have been described in cases of renal failure [69] and increases in CK in muscle damage [67].

There is still much knowledge to be generated for the basis of the interpretation of the analytes that can be included in the sialochemistry profile in saliva. To help in this interpretation, the clarification of the mechanism involved in the presence of each analyte in saliva, and data about their correlations between serum and saliva, will be especially useful. In this regard, it should be pointed out that there are analytes present in saliva that are produced locally in the salivary glands. In addition, the analytes can pass from blood to saliva by different ways such as: passive diffusion in the case of lipophilic molecules like steroid hormones, active transport in case of some proteins or filtration through spaces between acinus and ductal cells in case of small molecules [4].

Possibly some of these analytes could have a similar interpretation and clinical value that in serum, such as it was reported for urea and creatinine in dogs [69] and also occurs with the acute phase proteins; whereas others could have a different interpretation. In addition, some other analytes could be more sensitive to detect some processes when measured in saliva than in serum, as occurs with ADA [57]). Ideally, specificity and sensitivity of different analytes in saliva in comparison with serum or urine should be evaluated in different stress or specific disease conditions in pigs, as it has been made in humans [70]. This evaluation could be done by individual analytes or also combined in algorithms. 


\section{Conclusions}

The saliva of pigs can be used to measure biomarkers that can help to evaluate stress, inflammation, immune system and redox homeostasis. These biomarkers, as well as the sialochemistry profiles, reflect that the saliva, in addition to be a diagnostic tool for infectious disease detection, can provide potential interesting information about the health and welfare status of the pig. However, there is still need of more data in order to validate the use of saliva in this field. Therefore, it is expected that in the near future, more knowledge about their physiology and practical applications will be generated on the salivary markers reviewed here, and also on new ones that could be discovered, especially by "omics" techniques. This knowledge expected to be generated will provide more precise and useful information about these biomarkers, contributing to a wider use of saliva in this species as well as other animal species and humans in the future.

\begin{abstract}
Abbreviations
ADA: Adenosine deaminase; ADA1: Adenosine deaminase isoenzyme 1; ADA2: Adenosine deaminase isoenzyme 2; ALP: Alkaline phosphatase; ANS: Autonomous nervous system; AOPP: Advanced oxidation protein products; APPs: Acute phase proteins; AST: Aspartate aminotransferase; BChE: Butyrylcholinesterase; CA-Vl: Carbonic anhydrase isoenzyme 6; CgA: Chromogranin A; ChE: Cholinesterase; CK: Creatine kinase; CRP: C-reactive protein; CUPRAC: Cupric reducing antioxidant capacity; EHNA: Erythro-9-2-hydroxy-3-nonyl adenine; ELISA: Enzyme-linked-immunoassay; FRAS: Ferric reducing ability of saliva; $\mathrm{Hp}$ : Haptoglobin; $\mathrm{H}_{2} \mathrm{O}_{2}$ : Hydrogen peroxide; GGT: $\gamma$-glutamine transferase; HPA: Hypothalamic-pituitary-adrenal axis; Igs: Immunoglobulins; LDH: Lactate dehydrogenase; OT: Oxytocin; PDS: Postpartum dysgalactia syndrome; PMWS: Post-weaning multisystemic wasting syndrome; PRRS: Porcine reproductive and respiratory syndrome; sAA: Salivary alpha-amylase; sLip: Salivary lipase; TAC: Total antioxidant capacity; tADA: Total adenosine deaminase; TEA: Total esterase activity; TEAC: Trolox equivalent antioxidant capacity.
\end{abstract}

\section{Acknowledgments}

Authors would like to acknowledge to all the researchers, companies and practitioners that have collaborated with them in the field of saliva analysis and that made possible the generation of new knowledge in this topic.

\section{Authors' contributions}

JJC, SMS and FT contributed to the conception of the review. JJC, MDCA, DE, SMM, MJLM, AOB, LFM, CPR, AMP, AT, MLA, SMS and FT contributed to the data collection and analysis and drafting and revision of the manuscript, all authors read and approved the final manuscript.

\section{Funding}

The study was funded by the Seneca Foundation of Murcia Region, Spain, with grant number 19849/GERM/15).

\section{Availability of data and materials}

All data analyzed during this study is included in this published article.

\section{Declarations}

Ethics approval and consent to participate

Not applicable.

\section{Consent for publication}

Not applicable.

\section{Competing interests}

The authors declare that there are no conflicts of interest.

\section{Author details}

${ }^{1}$ Interdisciplinary Laboratory of Clinical Analysis, Interlab-UMU, Regional Campus of International Excellence 'Campus Mare Nostrum,' University of Murcia, 30100 Murcia, Spain. ${ }^{2}$ Department of Animal Production, Regional Campus of International Excellence 'Campus Mare Nostrum', University of Murcia, Campus de Espinardo s/n, 30100 Espinardo, Murcia, Spain.

Received: 24 September 2021 Accepted: 15 February 2022

Published online: 28 February 2022

\section{References}

1. Lamy E, Mau M. Saliva proteomics as an emerging, non-invasive tool to study livestock physiology, nutrition and diseases. J Proteome. 2012;75:4251-8. https://doi.org/10.1016/J.JPROT.2012.05.007.

2. Tvarijonaviciute A, Martínez-Subiela S, López-Jornet P, Lamy E. Saliva in health and disease the present and future of a unique sample for diagnosis; 2020.

3. Gröschl M. Current status of salivary hormone analysis. Clin Chem. 2008:54:1759-69. https://doi.org/10.1373/CLINCHEM.2008.108910.

4. Pfaffe T, Cooper-White J, Beyerlein P, Kostner K, Punyadeera C. Diagnostic potential of saliva: current state and future applications. Clin Chem. 2011;57:675-87. https://doi.org/10.1373/CLINCHEM.2010.153767.

5. Merlot E, Mounier A, Prunier A. Endocrine response of gilts to various common stressors: a comparison of indicators and methods of analysis. Physiol Behav. 2011;102:259-65. https://doi.org/10.1016/J.PHYSBEH.2010.11.009.

6. Martínez-Miró S, Tecles F, Ramón M, Escribano D, Hernández F, Madrid J, et al. Causes, consequences and biomarkers of stress in swine: an update. BMC Vet Res. 2016;12. https://doi.org/10.1186/S12917-016-0791-8.

7. Cerón J. Acute phase proteins, saliva and education in laboratory science: an update and some reflections. BMC Vet Res. 2019;15. https://doi.org/10. 1186/S12917-019-1931-8.

8. Cook NJ, Schaefer AL, Lepage P, Jones SM. Salivary vs. serum cortisol for the assessment of adrenal activity in swine, vol. 76; 2011. p. 329-35. https://doi.org/10.4141/cjas96-049.

9. Henao-Diaz A, Giménez-Lirola L, Baum D, Zimmerman J. Guidelines for oral fluid-based surveillance of viral pathogens in swine. Porc Heal Manag. 2020;6. https://doi.org/10.1186/S40813-020-00168-W.

10. Escribano D, Fuentes-Rubio M, Cerón J. Validation of an automated chemiluminescent immunoassay for salivary cortisol measurements in pigs. JVet Diagn Investig. 2012;24:918-23. https://doi.org/10.1177/1040638712455171.

11. Thomsson O, Ström-Holst B, Sjunnesson Y, Bergqvist A. Validation of an enzyme-linked immunosorbent assay developed for measuring cortisol concentration in human saliva and serum for its applicability to analyze cortisol in pig saliva. Acta Vet Scand. 2014;56:55. https://doi.org/10.1186/ S13028-014-0055-1.

12. Rey-Salgueiro L, Martinez-Carballo E, Fajardo P, Chapela M, Espiñeira M, Simal-Gandara J. Meat quality in relation to swine well-being after transport and during lairage at the slaughterhouse. Meat Sci. 2018;142:38-43. https://doi.org/10.1016/J.MEATSCI.2018.04.005.

13. Ruis M, Te Brake J, Engel B, Ekkel E, Buist W, Blokhuis $H$, et al. The circadian rhythm of salivary cortisol in growing pigs: effects of age, gender, and stress. Physiol Behav. 1997;62:623-30. https://doi.org/10.1016/S00319384(97)00177-7.

14. Prims S, Vanden Hole C, Van Cruchten S, Van Ginneken C, Van Ostade X, Casteleyn C. Hair or salivary cortisol analysis to identify chronic stress in piglets? Vet J. 2019;252. https://doi.org/10.1016/J.TVJL.2019.105357.

15. Bahnsen I, Riddersholm K, de Knegt L, Bruun T, Amdi C. The effect of different feeding systems on salivary cortisol levels during gestation in sows on herd level. Anim an open access J from MDPI. 2021;11. https://doi.org/ 10.3390/ANI11041074.

16. Deng J, Cheng C, Yu H, Huang S, Hao X, Chen J, et al. Inclusion of wheat aleurone in gestation diets improves postprandial satiety, stress status and stillbirth rate of sows. Anim Nutr (Zhongguo xu mu shou yi xue hui). 2021;7:412-20. https://doi.org/10.1016/J.ANINU.2020.06.015.

17. López-Arjona M, Tecles F, Mateo S, Contreras-Aguilar M, Martínez-Miró S, Cerón J, et al. Measurement of cortisol, cortisone and 11ß-hydroxysteroid 
dehydrogenase type 2 activity in hair of sows during different phases of the reproductive cycle. Vet J. 2020:259-60. https://doi.org/10.1016/JTVJL. 2020.105458

18. Escribano D, Fuentes-Rubio M, Cerón J. Salivary testosterone measurements in growing pigs: validation of an automated chemiluminescent immunoassay and its possible use as an acute stress marker. Res Vet Sci. 2014;97:20-5. https://doi.org/10.1016/J.RVSC.2014.04.001.

19. Romero-Martínez A, González-Bono E, Lila M, Moya-Albiol L. Testosterone/cortisol ratio in response to acute stress: a possible marker of risk for marital violence. Soc Neurosci. 2013;8:240-7.

20. Contreras-Aguilar M, Escribano D, Martínez-Subiela S, Martínez-Miró S, Cerón J, Tecles F. Changes in alpha-amylase activity, concentration and isoforms in pigs after an experimental acute stress model: an exploratory study. BMC Vet Res. 2018;14. https://doi.org/10.1186/S12917-018-1581-2.

21. Contreras-Aguilar M, Escribano D, Martínez-Subiela S, Martínez-Miró S, Rubio M, Tvarijonaviciute A, et al. Influence of the way of reporting alphaamylase values in saliva in different naturalistic situations: a pilot study. PLoS One. 2017;12. https://doi.org/10.1371/JOURNAL.PONE.0180100.

22. Escribano D, Soler L, Gutiérrez AM, Martínez-Subiela S, Cerón JJ. Measurement of chromogranin a in porcine saliva: validation of a time-resolved immunofluorometric assay and evaluation of its application as a marker of acute stress. Animal. 2013;7:640-7. https://doi.org/10.1017/S1751731112002005.

23. Fuentes M, Tecles F, Gutiérrez A, Otal J, Martínez-Subiela S, Cerón J. Validation of an automated method for salivary alpha-amylase measurements in pigs (Sus scrofa domesticus) and its application as a stress biomarker. J Vet Diagn Investig. 2011;23:282-7. https://doi.org/10.1177/104063871102300213.

24. Huang Y, Liu Z, Liu W, Yin C, Ci L, Zhao R, et al. Short communication salivary haptoglobin and chromogranin a as non-invasive markers during restraint stress in pigs. Res Vet Sci. 2017;114:27-30. https://doi.org/10. 1016/J.RVSC.2017.02.023.

25. Escribano D, Ko H, Chong Q, Llonch L, Manteca X, Llonch P. Salivary biomarkers to monitor stress due to aggression after weaning in piglets. Res Vet Sci. 2019;123:178-83. https://doi.org/10.1016/J.RVSC.2019.01.014.

26. Escribano D, Gutiérrez A, Fuentes-Rubio M, Cerón J. Saliva chromogranin a in growing pigs: a study of circadian patterns during daytime and stability under different storage conditions. Vet J. 2014;199:355-9. https:// doi.org/10.1016/J.TVJL.2014.01.005.

27. Contreras-Aguilar M, Escribano D, Martínez-Miró S, López-Arjona L, Rubio C, Martínez-Subiela S, et al. Application of a score for evaluation of pain, distress and discomfort in pigs with lameness and prolapses: correlation with saliva biomarkers and severity of the disease. Res Vet Sci. 2019:126:155-63. https://doi.org/10.1016/J.RVSC.2019.08.004

28. Casal N, Manteca X, Escribano D, Cerón J, Fàbrega E. Effect of environmental enrichment and herbal compound supplementation on physiological stress indicators (chromogranin a, cortisol and tumour necrosis factor-a) in growing pigs. Animal. 2017;11:1228-36. https://doi.org/10. 1017/S1751731116002561.

29. Kaiser M, Jacobsen S, Andersen P, Bækbo P, Cerón J, Dahl J, et al. Hormonal and metabolic indicators before and after farrowing in sows affected with postpartum dysgalactia syndrome. BMC Vet Res. 2018;14. https:// doi.org/10.1186/S12917-018-1649-Z

30. Tecles F, Contreras-Aguilar M, Martínez-Miró S, Tvarijonaviciute A, Martínez-Subiela S, Escribano D, et al. Total esterase measurement in saliva of pigs: validation of an automated assay, characterization and changes in stress and disease conditions. Res Vet Sci. 2017;114:170-6. https://doi. org/10.1016/J.RVSC.2017.04.007.

31. Sayer R, Law E, Connelly P, Breen K. Association of a salivary acetylcholinesterase with Alzheimer's disease and response to cholinesterase inhibitors. Clin Biochem. 2004;37:98-104. https://doi.org/10.1016/J.CLINB IOCHEM.2003.10.007.

32. Tecles F, Escribano D, Martínez-Miró S, Hernández F, Contreras MD, Cerón JJ. Cholinesterase in porcine saliva: analytical characterization and behavior after experimental stress. Res Vet Sci. 2016;106:23-8.

33. Ryhanen R, Narhi M, Puhakainen E, Hanninen O, Kontturi-Narhi V. Pseudocholinesterase activity and its origin in human Oral fluid. J Dent Res. 1983:62:20-3.

34. Fedorova T, Knudsen C, Mouridsen K, Nexo E, Borghammer P. Salivary acetylcholinesterase activity is increased in Parkinson's disease: a potential marker of parasympathetic dysfunction. Parkinsons Dis. 2015;2015. https://doi.org/10.1155/2015/156479.
35. Lee PC, Purcell ES, Borysewicz R, Klein RM, Werlin SL. Developmental delay of lingual lipase expression after Guanethidine-induced Sympathectomy. Proc Soc Exp Biol Med. 1992;199:192-8.

36. Henkin RI, Martin BM, Agarwal RP. Decreased parotid saliva Gustin/carbonic anhydrase VI secretion: an enzyme disorder manifested by gustatory and olfactory dysfunction. Am J Med Sci. 1999;318:380.

37. Kivelä J, Parkkila S, Parkkila AK, Leinonen J, Rajaniemi H. Salivary carbonic anhydrase isoenzyme VI. J Physiol. 1999;520:315-20.

38. López-Arjona M, Escribano D, Mateo SV, Contreras-Aguilar MD, Rubio CP, Tecles F, et al. Changes in oxytocin concentrations in saliva of pigs after a transport and during lairage at slaughterhouse. Res Vet Sci. 2020;133:26-30.

39. López-Arjona M, Mateo S, Manteca X, Escribano D, Cerón J, MartínezSubiela S. Oxytocin in saliva of pigs: an assay for its measurement and changes after farrowing. Domest Anim Endocrinol. 2020;70. https://doi. org/10.1016/J.DOMANIEND.2019.106384.

40. Alaerts K, Steyaert J, Vanaudenaerde B, Wenderoth N, Bernaerts S. Changes in endogenous oxytocin levels after intranasal oxytocin treatment in adult men with autism: an exploratory study with long-term follow-up. Eur Neuropsychopharmacol. 2021;43:147-52. https://doi.org/ 10.1016/J.EURONEURO.2020.11.014.

41. MacLean E, Wilson S, Martin W, Davis J, Nazarloo H, Carter C. Challenges for measuring oxytocin: the blind men and the elephant? Psychoneuroendocrinology. 2019;107:225-31. https://doi.org/10.1016/J.PSYNEUEN.2019.05.018.

42. López-Arjona M, Mateo S, Escribano D, Tecles F, Cerón J, Martínez-Subiela S. Effect of reduction and alkylation treatment in three different assays used for the measurement of oxytocin in saliva of pigs. Domest Anim Endocrinol. 2021;74. https://doi.org/10.1016/J.DOMANIEND.2020.106498.

43. Lürzel S, Bückendorf L, Waiblinger S, Rault J. Salivary oxytocin in pigs, cattle, and goats during positive human-animal interactions. Psychoneuroendocrinology. 2020;115. https://doi.org/10.1016/J.PSYNEUEN.2020.104636.

44. MacLean E, Gesquiere L, Gee N, Levy K, Martin W, Carter C. Validation of salivary oxytocin and vasopressin as biomarkers in domestic dogs. J Neurosci Methods. 2018;293:67-76. https://doi.org/10.1016/J.JNEUMETH.2017.08.033.

45. López-Arjona M, Padilla L, Roca J, Cerón J, Martínez-Subiela S. Ejaculate collection influences the salivary oxytocin concentrations in breeding male pigs. Anim an open access J from MDPI. 2020;10:1-12. https://doi. org/10.3390/ANI10081268.

46. Contreras-Aguilar M, López-Arjona M, Martínez-Miró S, Escribano D, Hernández-Ruipérez F, Cerón J, et al. Changes in saliva analytes during pregnancy, farrowing and lactation in sows: a sialochemistry approach. Vet J. 2021;273. https://doi.org/10.1016/J.TVJL.2021.105679.

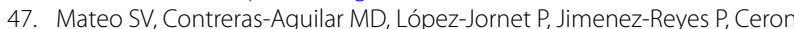
$\mathrm{JJ}$, Tvarijonaviciute A, et al. Development and evaluation of a rapid and sensitive homogeneous assay for haptoglobin measurements in saliva. Microchem J. 2019;150.

48. Lin G, Küng E, Smaj|hodzic M, Domazet S, Friedl H, Angerer J, et al. Directed transport of CRP across in vitro models of the blood-saliva barrier strengthens the feasibility of salivary CRP as biomarker for neonatal Sepsis. Pharmaceutics. 2021;13:1-17. https://doi.org/10.3390/PHARMACEUTICS13020256.

49. Escribano D, Campos P, Gutiérrez A, Le Floc'h N, Cerón J, Merlot E. Effect of repeated administration of lipopolysaccharide on inflammatory and stress markers in saliva of growing pigs. Vet J. 2014;200:393-7. https://doi. org/10.1016/J.TVJL.2014.04.007.

50. Ott S, Soler L, Moons C, Kashiha M, Bahr C, Vandermeulen J, et al. Different stressors elicit different responses in the salivary biomarkers cortisol, haptoglobin, and chromogranin a in pigs. Res Vet Sci. 2014;97:124-8. https:// doi.org/10.1016/J.RVSC.2014.06.002.

51. Escribano D, Gutiérrez A, Tecles F, Cerón J. Changes in saliva biomarkers of stress and immunity in domestic pigs exposed to a psychosocial stressor. Res Vet Sci. 2015;102:38-44. https://doi.org/10.1016/J.RVSC.2015.07.013.

52. Tecles F, Fuentes P, Martínez Subiela S, Parra M, Muñoz A, Cerón J. Analytical validation of commercially available methods for acute phase proteins quantification in pigs. Res Vet Sci. 2007;83:133-9. https://doi.org/10. 1016/J.RVSC.2006.10.005

53. Murata H. Stress and acute phase protein response: an inconspicuous but essential linkage. Vet J. 2007;173:473-4. https://doi.org/10.1016/J.TVJL. 2006.05.008.

54. Baganha M, Pêgo A, Lima M, Gaspar E, Cordeiro A. Serum and pleural adenosine deaminase. Correlation with lymphocytic populations. Chest. 1990;97:605-10. https://doi.org/10.1378/CHEST.97.3.605. 
55. Mishra OP, Gupta BL, Ali Z, Nath G, Chandra L. Adenosine deaminase activity in typhoid fever. Indian Pediatr. 1994;31:1379-84.

56. Tecles F, Rubio C, Contreras-Aguilar M, López-Arjona M, Martínez-Miró S, Martínez-Subiela S, et al. Adenosine deaminase activity in pig saliva: analytical validation of two spectrophotometric assays. J Vet Diagn Investig. 2018;30:175-9. https://doi.org/10.1177/1040638717742947.

57. Contreras-Aguilar M, Tvarijonaviciute A, Monkeviciene I, Martín-Cuervo M, González-Arostegui L, Franco-Martínez L, et al. Characterization of total adenosine deaminase activity (ADA) and its isoenzymes in saliva and serum in health and inflammatory conditions in four different species: an analytical and clinical validation pilot study. BMC Vet Res. 2020;16. https:// doi.org/10.1186/S12917-020-02574-2.

58. Escribano D, Gutiérrez A, Martínez Subiela S, Tecles F, Cerón J. Validation of three commercially available immunoassays for quantification of $\lg A$, IgG, and IgM in porcine saliva samples. Res Vet Sci. 2012;93:682-7. https:// doi.org/10.1016/J.RVSC.2011.09.018.

59. Muneta Y, Yoshikawa T, Minagawa Y, Shibahara T, Maeda R, Omata Y. Salivary IgA as a useful non-invasive marker for restraint stress in pigs. J Vet Med Sci. 2010;72:1295-300. https://doi.org/10.1292/JVMS.10-0009.

60. Parry J, Perry K, Mortimer P. Sensitive assays for viral antibodies in saliva: an alternative to tests on serum. Lancet (London, England). 1987;2:72-5. https://doi.org/10.1016/S0140-6736(87)92737-1.

61. Brandtzaeg P. Secretory immunity with special reference to the oral cavity. J Oral Microbiol. 2013;5. https://doi.org/10.3402/JOM.V510.20401.

62. Allgrove J, Gomes E, Hough J, Gleeson M. Effects of exercise intensity on salivary antimicrobial proteins and markers of stress in active men. J Sports Sci. 2008;26:653-61. https://doi.org/10.1080/02640410701716790.

63. Rubio C, Mainau E, Cerón J, Contreras-Aguilar M, Martínez-Subiela S,

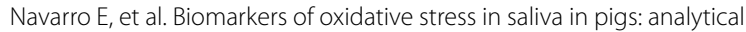
validation and changes in lactation. BMC Vet Res. 2019;15. https://doi. org/10.1186/S12917-019-1875-Z.

64. Rivera-Gomis J, Rubio C, Martínez Conesa C, Otal Salaverri J, Cerón J, Escribano Tortosa D, et al. Effects of dietary supplementation of garlic and oregano essential oil on biomarkers of oxidative status, stress and inflammation in Postweaning piglets. Anim an open access J from MDPI. 2020;10:1-17. https://doi.org/10.3390/ANI10112093.

65. Escribano D, Contreras-Aguilar M, Tvarijonaviciute A, Martínez-Miró S, Martínez-Subiela S, Cerón J, et al. Stability of selected enzymes in saliva of pigs under different storage conditions: a pilot study. J Vet Med Sci. 2018;80:1657-61. https://doi.org/10.1292/JVMS.18-0346.

66. Barranco T, Rubio C, Tvarijonaviciute A, Rubio M, Damia E, Lamy E, et al. Changes of salivary biomarkers under different storage conditions: effects of temperature and length of storage. Biochem medica. 2019;29. https://doi.org/10.11613/BM.2019.010706.

67. Tvarijonaviciute A, Barranco T, Rubio M, Carrillo J, Martinez-Subiela S, Tecles F, et al. Measurement of Creatine kinase and aspartate aminotransferase in saliva of dogs: a pilot study. BMC Vet Res. 2017;13. https://doi. org/10.1186/S12917-017-1080-X.

68. Escribano D, Horvatić A, Contreras-Aguilar MD, Guillemin N, Cerón JJ, Tecles F, et al. Changes in saliva proteins in two conditions of compromised welfare in pigs: an experimental induced stress by nose snaring and lameness. Res Vet Sci. 2019;125:227-34.

69. Tvarijonaviciute A, Pardo-Marin L, Tecles F, Carrillo J, Garcia-Martinez J, Bernal $L$, et al. Measurement of urea and creatinine in saliva of dogs: a pilot study. BMC Vet Res. 2018;14. https://doi.org/10.1186/S12917-018-1546-5.

70. Porto-Mascarenhas EC, Assad DX, Chardin H, Gozal D, De Luca CG, Acevedo AC, et al. Salivary biomarkers in the diagnosis of breast cancer: a review. Crit Rev Oncol Hematol. 2017;110:62-73. https://doi.org/10. 1016/J.CRITREVONC.2016.12.009.

\section{Publisher's Note}

Springer Nature remains neutral with regard to jurisdictional claims in published maps and institutional affiliations.
Ready to submit your research? Choose BMC and benefit from:

- fast, convenient online submission

- thorough peer review by experienced researchers in your field

- rapid publication on acceptance

- support for research data, including large and complex data types

- gold Open Access which fosters wider collaboration and increased citations

- maximum visibility for your research: over $100 \mathrm{M}$ website views per year

At BMC, research is always in progress.

Learn more biomedcentral.com/submissions 